\title{
Taxonomy of the phyllosoma of Panulirus inflatus (Bouvier, 1895) and $P$. gracilis Streets, 1871 , based on morphometry and molecular analysis
}

Isabel Muñoz-García*, Francisco J. García-Rodríguez, Rogelio González-Armas, Ricardo PerezEnriquez and Manuel Ayón-Parente

(IMG) Facultad de Ciencias del Mar, Universidad Autónoma de Sinaloa (UAS-FACIMAR), Apdo. Postal 610, Mazatlán, Sinaloa 82000, Mexico. E-mail: isamuga@hotmail.com *Corresponding author

(IMG) (FJGR) (RGA) Centro Interdisciplinario de Ciencias Marinas-Instituto Politécnico Nacional, Avenida IPN s/n, La Paz, B.C.S. 23096, Mexico

(RPE) Centro de Investigaciones Biológicas del Noroeste (CIBNOR), Calle IPN \#195, La Paz, B.C.S. 23096, Mexico

(MAP) Universidad de Guadalajara, Departamento de Ecología, CUCBA, Carretera a Nogales Km. 15.5, Las Agujas Nextipac, Zapopan, Jalisco 45110, Mexico

\begin{abstract}
Analysis of wild phyllosoma of Panulirus inflatus (Bouvier, 1895) and $P$. gracilis Streets, 1871 determined the morphological structures having taxonomic value for differentiation of the two species, in addition to the structures described previously. Of 54 phyllosoma, species identity was confirmed by PCR-restriction fragment length polymorphism (RFLP) on 42 P. inflatus and 4 P. gracilis, for which morphology and morphometric measurements were taken. Morphological analysis found subexopodal spines, spines at the base of pereopods 1 and 2 , and the mandibles are structures of taxonomic value for differentiating the two species. Morphometric data did not allow differentiation.
\end{abstract}

Key Words: Larvae, Pacific coast of Mexico, PCR-RFLP, spiny lobsters, taxonomy

\section{INTRODUCTION}

The distribution of the blue spiny lobster Panulirus inflatus (Bouvier, 1895) and the green spiny lobster Panulirus gracilis Streets, 1871 overlaps along the Pacific coast of Mexico (Holthuis and Villalobos, 1962; Chapa-Saldaña, 1964; Hendrickx, 1995). In the central part of the west coast of the Baja California Peninsula, the distribution overlaps with the commercially important California spiny lobster, Panulirus interruptus (Randall, 1840) of Mexico (Holthuis and Villalobos, 1962; Campos, 2007).

Additional information on larval biology is needed to understand the dynamics of lobster distribution and recruitment in their respective fishing grounds and for commercial stock management. The taxonomic features of the long development $(73 / 4$ months for $P$. interruptus and 9 months for $P$. inflatus and P. gracilis) of larval stages of these species were described using specimens collected at sea by Johnson (1971), Johnson and Knight (1966), and Baez (1983). They determined that subexopodal spines differentiate the three species, since they are absent in P. interruptus and present in the first three pairs of walking legs (pereopods) of P. inflatus and P. gracilis.

However, the two similar species can be distinguished only from larval stage IV, when the fourth pereopods are developed, in which subexopodal spines are present in $P$. gracilis, but absent in P. inflatus (Johnson, 1956, 1971; Johnson and Knight, 1966). Because the 
pereopods of these larvae are fragile structures and are easily broken and lost, some alternative structures are needed to differentiate $P$. gracilis from $P$. inflatus at the larval stage (phyllosoma). In $P$. gracilis phyllosomes, there are two or three setae present on the external base of the first segment of the antennular peduncle and one on the outer margin of the third segment of the endopod of the second maxilliped (Baez, 1983). None of these are present in P. inflatus (Báez, 1983).

Despite this knowledge, identification of $P$. inflatus and $P$. gracilis phyllosoma remains difficult. The purpose of this study was to detect morphological or morphometric elements that allow its differentiation. To support the taxonomic identity of the specimens, molecular markers designed in a previous study of adult lobsters were used (García-Rodríguez et al., 2008). The application of molecular methods to identify marine larvae has increased to complement morphological identification (Richardson et al., 2007).

\section{Material and Methods}

Phyllosoma were obtained by surface plankton tows with $3 \mathrm{~m}$ Neuston nets $(500 \mu \mathrm{m}$ mesh size, $0.30 \times 0.50 \mathrm{~m}$ mouth) from a research vessel, during oceanographic cruise S-189 (November 2003, Station 082, 20 08'30"N, $106^{\circ} 48^{\prime} 02^{\prime \prime} \mathrm{W}, 48$ larvae) and cruise S-195 (November 2004, Station 073, 24 $4^{\circ} 18^{\prime} 48^{\prime \prime} \mathrm{N}$, $109^{\circ} 24^{\prime} 06^{\prime \prime} \mathrm{W}, 4$ larvae), and Station 076, $25^{\circ} 16^{\prime} 42^{\prime \prime} \mathrm{N}, 110^{\circ} 21^{\prime} 36^{\prime \prime} \mathrm{W}, 2$ larvae). The samples were immediately preserved in $70 \%$ ethanol.

Phyllosoma were identified (Johnson and Knight, 1966). Because the larvae were damaged, they were assigned to one of the following four groups, based on Johnson (1971) and Báez (1983), indicated by "a" and "b", respectively. Because no larvae on phyllosoma stages (I-IV) were collected, the morphological descriptions represent stages V-XI.

Panulirus spp. group: Larvae with subcircular or egg-shaped cephalic region (a). Pereopods, second maxilliped and antennule were lost.
Panulirus inflatus or $P$ gracilis group: Larvae with any of the pereopods 1 to 3 and subexopodal spine present (a). Fourth pereopod, second maxilliped and antennule lost.

Panulirus gracilis group: Larvae with subexopodal spine present in pereopods 1 to 4 and (a) or with two or three setae on the outer margin of the basal segment of the antennule and one in the third segment of the endopod of second maxilliped (b).

Panulirus inflatus group: Larvae with subexopodal spine on pereopods 1 to 3 and without subexopodal spine in the 4th (a) or no setae on the outer margin of the basal segment of the antennule or on the third segment of the endopod of second maxilliped (b).

Species identity was determined by RFLP (restriction fragment-length polymorphism) genetic analysis, as described by GarcíaRodríguez et al. (2008). Briefly, a small portion of body tissue of each individual was used for extracting DNA by direct digestion in a lysis buffer. The 16SrRNA gene fragment, of about 563 bp of the mitochondrial DNA, was amplified using $16 \mathrm{Sar}-\mathrm{L}$ and $16 \mathrm{Sbr}-\mathrm{H}$ primers (Palumbi et al., 1991). PCR fragments were digested using two restriction enzymes (BsmAI and $\operatorname{Hinfl}$ ) and the resulting fragments were separated by $2 \%$ agarose gel electrophoresis and stained with SybrGold (Invitrogen, Carlsbad, CA). The compound haplotype produced by digestion with both enzymes permitted identification of lobster larvae (García-Rodríguez et al., 2008).

Measurements of each larva (Fig. 1A) included: total length (TL) from the anterior edge of the cephalic region between the eyes to the tip of the telson; cephalic region length (CRL) from the anterior margin between the eyes to the posterior margin; width of the cephalic region (CRW) from right to left along the widest part of the cephalic region; thoracic width (THW) from right to left margin at the base of the second pereopods; thoracic length (THL) from the base of the second maxilla to the base of coxae of the 4th pereopod; abdomen length $(\mathrm{ABL})$ from the anterior margin of the abdomen to the posterior margin of telson; 
abdomen width (ABW) at the junction with the thorax; length of the buccal appendage (BAL) from the tip of the labrum to the base of the coxal endite of the first maxilla; width of the buccal appendage (BAW) from left margin of the left mandible to the right margin of the right mandible; distance between the second maxillipeds (M2D); the distance between the base of the first maxilla to the posterior margin of the cephalic region (M1C); distance between the base of the buccal appendage to the intermediate part of the base of the second maxillipeds (BAM).

Setae were counted on the antennular peduncle, the second maxilliped (Fig. 1B, C), the coxal and basal endite of the first maxilla, the coxae, and on the base of each pereopod (Watling, 1989). The number of aesthetascs at the external branch of the antennule and the coxal, basal, and subexopodal spines of each pereiopod were also counted.

Dissections and drawings were performed with camera-equipped microscopes, the Nikon SMZ-10A stereoscopic microscope and the Leitz Ortholux II optical microscope.

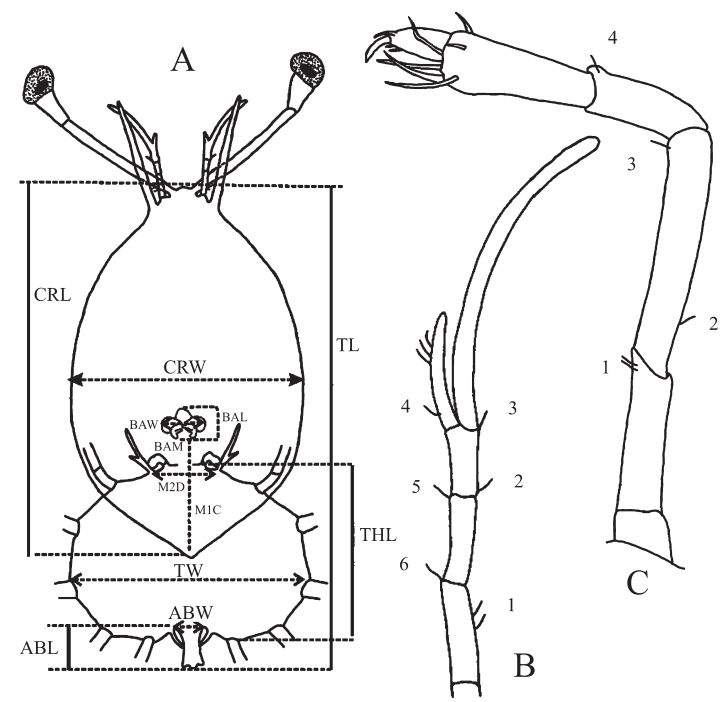

Figure 1. Morphometric, setae and aesthetascs determined for each phyllosoma. [A] total length (TL), length of cephalic region (CRL), width of cephalic region (CRW), thorax width (TW), thorax length (THL), abdomen length (ABL), abdomen width (ABW), length of the buccal appendage (BAL), width of the buccal appendage (BAW), distance between the second maxillipeds (M2D), distance between the base of the first maxillary to posterior margin of cephalic region (M1C), distance between the base of the buccal appendage to the intermediate part of the base of the second maxillipeds (BAM); [B] setae and aesthetascs of antennule 1; [C] setae of maxilliped 2.

\section{Results}

We used 54 phyllosoma for genetic analysis at stages $\mathrm{V}$ to XI. The most abundant were stages VII and VIII. The larvae were initially classified as 10 Panulirus spp., 16 P. inflatus or P. gracilis, 18 P. inflatus, and 10 P. gracilis (Tab. 1). In 46 specimens, amplification of the 16SrRNA gene fragment was successful. Eight larvae, where DNA amplification was not obtainable, were discarded for morphometry analyses (Tab. 1).

Table 1. Number of larvae preclassified (group and stage) of two Panulirus species and confirmed through mitochondrial DNA (*not considered in morphometric analysis; FA: failed amplification).

\begin{tabular}{|c|c|c|c|c|c|c|c|c|}
\hline \multirow[b]{2}{*}{ Stage } & \multicolumn{4}{|c|}{ Preclassified (group and stage) } & \multirow[b]{2}{*}{ Total } & \multicolumn{2}{|c|}{$\begin{array}{c}\text { Confirmed by } \\
\text { mDNA }\end{array}$} & \multirow[b]{2}{*}{ FA } \\
\hline & $\begin{array}{c}\text { Panulirus } \\
\text { spp }\end{array}$ & $\begin{array}{l}\text { P. inflatus } \\
\text { or } \\
\text { P. gracilis }\end{array}$ & $\begin{array}{c}P . \\
\text { inflatus }\end{array}$ & $\begin{array}{c}P . \\
\text { gracilis }\end{array}$ & & $\begin{array}{c}P . \\
\text { inflatus }\end{array}$ & $\begin{array}{c}P . \\
\text { gracilis }\end{array}$ & \\
\hline$\overline{\mathrm{V}}$ & 0 & 0 & 1 & 0 & 1 & 1 & 0 & 0 \\
\hline VI & 0 & 1 & 5 & 2 & 8 & 7 & 1 & 0 \\
\hline VII & 4 & 5 & 5 & 4 & 18 & 14 & 1 & 3 \\
\hline VIII & 5 & 5 & 4 & 2 & 16 & 13 & 1 & 2 \\
\hline IX & 1 & 3 & 3 & 1 & 8 & 6 & 0 & 2 \\
\hline $\mathrm{X}$ & 0 & 2 & 0 & 0 & 2 & 1 & 0 & 1 \\
\hline $\mathrm{XI}(*)$ & 0 & 0 & 0 & 1 & 1 & 0 & 1 & 0 \\
\hline Total & 10 & 16 & 18 & 10 & 54 & 42 & 4 & 8 \\
\hline
\end{tabular}

The restriction pattern of 42 larvae with the combination of the two restriction enzymes (two fragments of $162 \mathrm{bp}$ and 401 bp with BsmAI; a single fragment of 563 bp with Hinfl), permitted identification as $P$. inflatus (García-Rodríguez et al., 2008; Fig. 2). The restriction pattern of four larvae resulted in three fragments with BsmAI digestion (401, 115, and $47 \mathrm{bp}$ ) and two with Hinfl (440 and123 bp) confirmed identity as $P$. gracilis (García-Rodríguez et al., 2008; Fig. 2). These results corrected for incorrect initial classification of two $P$. inflatus in the $P$. gracilis group and two $P$. gracilis in the $P$. inflatus group.

Morphometry: P. inflatus - All lengths and widths from stage $\mathrm{V}$ to $\mathrm{X}$ increased; the greatest change in TL was $13.9 \mathrm{~mm}(6.6 \mathrm{~mm}$ at $\mathrm{V}$ and $20.5 \mathrm{~mm}$ at $\mathrm{X}$ ), amounting to $210 \%$. The greatest increase was that of ABL (409.1\%, from $0.6 \mathrm{~mm}$ in $\mathrm{V}$ to $2.8 \mathrm{~mm}$ for $\mathrm{X}$ ) and the least important was that of M1C (46.7\%, from $1.5 \mathrm{~mm}$, stage $\mathrm{V}$ to $3.2 \mathrm{~mm}$, stage $\mathrm{X})$. The latter increased from stages V to IX (166.7\%) 


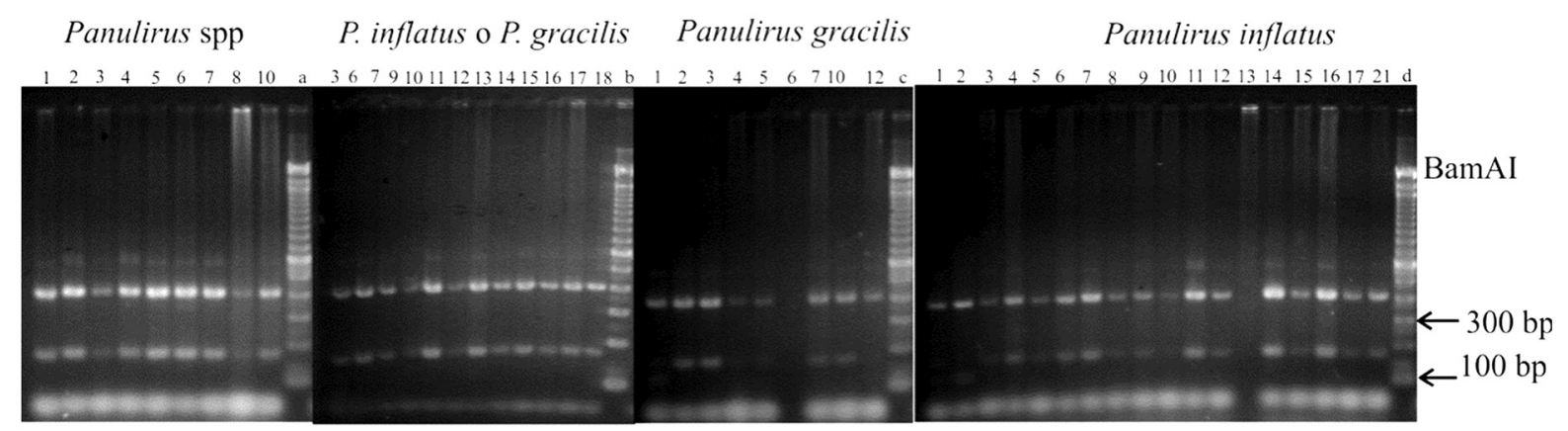

A

Panulirus spp P. inflatus o P. gracilis Panulirus gracilis Panulirus inflatus

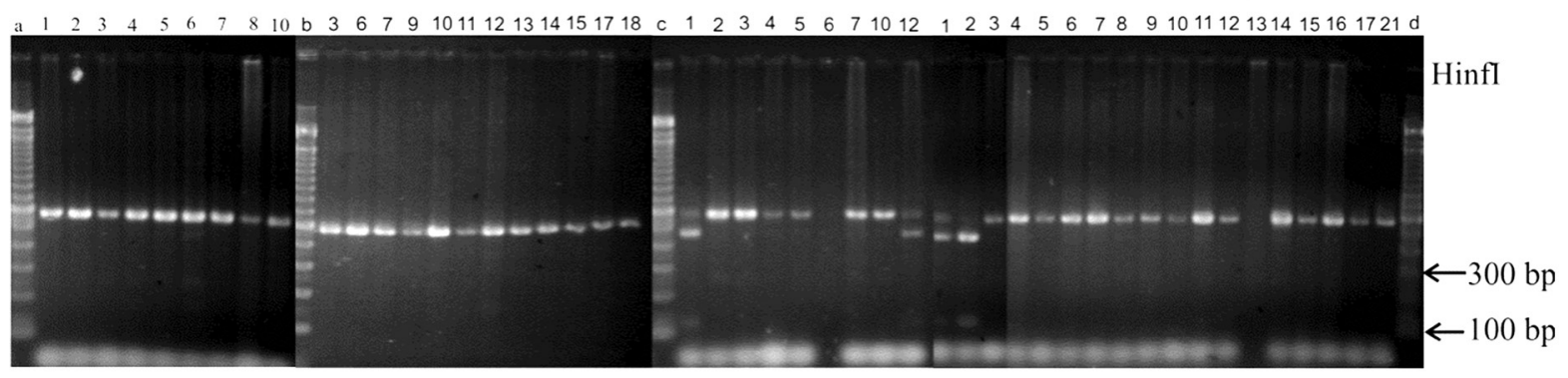

B

Figure 2. Electrophoresis patterns of the amplified fragment of the $16 \mathrm{~S}$ mitochondrial gene produced by digestion with BsmAI (A) and with Hinfl (B) for spiny lobsters larvae preclassified in four groups (Panulirus spp., P. inflatus or P. gracilis, P. gracilis and P. inflatus). Columns a, b, c, and d correspond to a commercial marker of known fragment sizes in base pairs (bp). Columns 1 and 12 of the gel of Panulirus gracilis group and columns 1 and 2 of the gel of Panulirus inflatus group correspond to P. gracilis.

but decreased later, between IX and X. The same tendency was observed for THL, ABW, and BAW (Tab. 2), although the significance of the decrease should be reassessed, since only one larva was available at stage X. In P. gracilis, all measurements increased from stage VI to VIII, the largest change in magnitude was that of TL (91.6\%: from $7.7 \mathrm{~mm}$ for stage VI to $14.8 \mathrm{~mm}$ for VIII) (Tab. 2).

Cephalic region: elliptical in both species, longer than wide, with a decreasing difference (1.6 times in stages V-VII to 1.4 in stages VIII-X). The ratio TL/CRL ranged between 1.3 and 1.4 (Tab. 2).

Thorax: slightly wider than long in all stages in both species. The ratio THW/THL ranged between 1.2 and 1.6, with a mean value of 1.4 . The ratio TL/THL increased in both species, ranging from 2.6 to 3.4 at stage $\mathrm{X}$. The ratio CRL/THL was between 1.9 and 2.4 in both species, and CRW/THW ranged between 0.9 (V-VIII) and $1.2(\mathrm{X})$ in P. inflatus and remained at 1.0 in $P$. gracilis (Tab. 2).

Abdomen: P. inflatus. Stage V: not segmented and with rudimentary uropods; stage
VI: cuticle with indications of segmentation; stage VII: cuticle segmented and uropods evident; stage IX: fifth somite with small lateral spines, uropod fully developed. Abdomen was proportionally longer than wide. At all stages, ABL/ABW increased from 1.4 at stage $V$ to 1.8 at stage $\mathrm{X}$. In general, abdomen increased in size and width in stages V-VII. The ratios TL/ ABL, CRL/ABL, and THL/ABL, and CRW/ $A B W$, and THW/ABW increased during stages V-VII, but decreased in stages VIII-X (Tab. 2, Fig. 3A-F). Pleopods absent at stage V, with small fissures at VI and VII, and slightly elongated slot on the surface at the distal end at VIII; elongated indicating biramous condition in IX and X. The forked branches had no clear basal joint (Fig. 3). Uropods at stage $\mathrm{V}$ were present as an outgrowth of the cuticle, at VI as small primordial, at VII as rudimentary uropods with small indentation in the distal surface, at VIII as well-defined slit showing the biramous condition, and at IX with branches clearly articulated toward the base and telson with several pores (Fig. 3E, F). 
Table 2. Mean values, standard deviation (S), and lowest and highest (Min and Max, respectively) morphometric measurements of phyllosoma larvae of Panulirus inflatus and Panulirus gracilis (in parenthesis, number of larvae used) and percentages of size increase. (TL) total length, (CRL) cephalic region length, (CRW) width of the cephalic region, (THW) thoracic width, (THL) thoracic length, (ABL) abdomen length, (ABW) abdomen width, (BAL) length of the buccal appendage, (BAW) width of the buccal appendage, (M2D) distance between second maxillipeds, (M1C) distance between the base of the first maxilla to the posterior margin of the cephalic region, (BAM) distance between the base of the buccal appendage to the intermediate portion of the base of the second maxillipeds.

\begin{tabular}{|c|c|c|c|c|c|c|c|c|c|c|c|c|c|}
\hline \multicolumn{2}{|c|}{ Structures } & $\mathrm{TL}$ & CRL & CRW & THL & \multicolumn{8}{|c|}{ Panulirus inflatus } \\
\hline \multicolumn{2}{|c|}{$\mathrm{V}(\mathrm{n}=1)$} & 6.60 & 4.90 & 3.11 & 2.31 & 3.21 & 0.55 & 0.40 & 0.40 & 0.58 & 0.45 & 0.91 & 1.50 \\
\hline & Mean & 8.35 & 6.33 & 3.99 & 2.93 & 4.10 & 0.65 & 0.39 & 0.46 & 0.66 & 0.53 & 1.23 & 1.86 \\
\hline \multirow{4}{*}{$\begin{array}{c}\mathrm{VI} \\
(\mathrm{n}=7)\end{array}$} & S & 0.33 & 0.29 & 0.20 & 0.18 & 0.22 & 0.05 & 0.02 & 0.04 & 0.04 & 0.02 & 0.07 & 0.10 \\
\hline & Min & 7.92 & 5.90 & 3.60 & 2.70 & 3.80 & 0.60 & 0.36 & 0.40 & 0.60 & 0.50 & 1.10 & 1.70 \\
\hline & $\operatorname{Max}$ & 8.70 & 6.70 & 4.20 & 3.20 & 4.40 & 0.71 & 0.42 & 0.50 & 0.70 & 0.55 & 1.30 & 2.00 \\
\hline & Mean & 10.76 & 8.15 & 5.27 & 3.82 & 5.33 & 0.84 & 0.61 & 0.54 & 0.77 & 0.68 & 1.54 & 2.41 \\
\hline \multirow{4}{*}{$\underset{(\mathrm{n}=14)}{\mathrm{VII}}$} & $S$ & 1.09 & 0.78 & 0.62 & 0.47 & 0.52 & 0.15 & 0.13 & 0.08 & 0.09 & 0.07 & 0.16 & 0.24 \\
\hline & Min & 8.15 & 6.20 & 3.85 & 2.85 & 4.10 & 0.65 & 0.40 & 0.40 & 0.57 & 0.55 & 1.20 & 1.80 \\
\hline & Max & 12.50 & 9.50 & 6.40 & 4.90 & 6.00 & 1.10 & 0.90 & 0.70 & 0.95 & 0.80 & 1.75 & 2.70 \\
\hline & Mean & 13.45 & 10.16 & 6.82 & 4.53 & 6.60 & 1.30 & 0.89 & 0.66 & 0.89 & 0.80 & 1.94 & 2.87 \\
\hline \multirow{4}{*}{$\begin{array}{c}\text { VIII } \\
(\mathrm{n}=13)\end{array}$} & $S$ & 1.28 & 0.94 & 0.75 & 0.44 & 0.75 & 0.18 & 0.15 & 0.06 & 0.08 & 0.04 & 0.21 & 0.42 \\
\hline & Min & 11.10 & 8.30 & 5.40 & 3.70 & 5.30 & 0.95 & 0.61 & 0.60 & 0.71 & 0.70 & 1.55 & 1.70 \\
\hline & Max & 15.10 & 11.15 & 7.80 & 5.00 & 7.90 & 1.60 & 1.10 & 0.80 & 1.00 & 0.85 & 2.20 & 3.20 \\
\hline & Mean & 16.34 & 12.00 & 8.37 & 5.47 & 7.72 & 1.92 & 1.24 & 0.78 & 1.09 & 1.00 & 2.38 & 3.53 \\
\hline \multirow{3}{*}{$\underset{(n=6)}{\text { IX }}$} & S & 1.93 & 1.20 & 1.16 & 0.89 & 0.85 & 0.49 & 0.29 & 0.10 & 0.15 & 0.20 & 0.28 & 0.40 \\
\hline & Min & 14.10 & 10.50 & 7.10 & 4.70 & 6.70 & 1.50 & 1.00 & 0.70 & 0.95 & 0.80 & 2.00 & 3.10 \\
\hline & Max & 18.80 & 13.50 & 10.00 & 7.10 & 8.90 & 2.60 & 1.65 & 0.90 & 1.31 & 1.20 & 2.65 & 4.00 \\
\hline \multicolumn{2}{|c|}{$\mathrm{X}(\mathrm{n}=1)$} & 20.50 & 14.80 & 10.60 & 6.10 & 9.00 & 2.80 & 1.60 & 0.90 & 1.20 & 1.20 & 2.70 & 2.20 \\
\hline \multicolumn{14}{|c|}{$\%$ increase in size for $P$. inflatus } \\
\hline \multirow{2}{*}{\multicolumn{2}{|c|}{$\begin{array}{c}\text { V-X } \\
\text { V-IX }\end{array}$}} & 210.61 & 202.04 & 240.84 & 164.07 & 180.37 & 409.09 & 300.00 & 125.00 & 106.90 & 166.67 & 196.70 & 46.67 \\
\hline & & & & & 207.36 & & & 312.50 & & 125.86 & & & 166.67 \\
\hline \multicolumn{14}{|c|}{ Panulirus gracilis } \\
\hline \multicolumn{2}{|c|}{$\mathrm{VI}(\mathrm{n}=1)$} & 7.70 & 5.80 & 3.71 & 2.70 & 3.71 & 0.59 & 0.33 & 0.41 & 0.60 & 0.60 & 1.05 & 1.80 \\
\hline \multicolumn{2}{|c|}{ VII $(n=1)$} & 12.25 & 9.15 & 6.10 & 4.40 & 6.20 & 1.15 & 0.79 & 0.65 & 0.80 & 0.70 & 1.85 & 2.90 \\
\hline \multicolumn{2}{|c|}{ VIII $(n=1)$} & 14.75 & 10.75 & 7.50 & 4.70 & 7.50 & 1.60 & 1.05 & 0.70 & 1.00 & 0.70 & 2.30 & 3.05 \\
\hline \multicolumn{14}{|c|}{$\%$ increase in size (VI-VIII) } \\
\hline \multicolumn{2}{|c|}{ P. inflatus } & 90.66 & 88.98 & 116.67 & 85.19 & 107.89 & 166.67 & 205.56 & 100.00 & 66.67 & 70.00 & 100.00 & 88.24 \\
\hline \multicolumn{2}{|c|}{ P. gracilis } & 91.56 & 85.34 & 102.16 & 74.07 & 102.16 & 171.19 & 218.18 & 70.73 & 66.67 & 16.67 & 119.05 & 69.44 \\
\hline
\end{tabular}

Abdomen: P. gracilis (VIII) with segmented cuticle. Pleopods appear as small primordia. Uropods rudimentary with small indentation at the surface of its distal area and three setae in the distal area of the outer branch (Fig. 3G1, G2). Abdomen at stages VI to VIII longer than wide, the ratio ABL/ ABW decreased from 1.8 at VI to 1.5 at VIII. In general, the abdomen increased in size and width from VI to VIII. The ratios TL/ABL, CRL/ABL, THL/ABL, CRW/AW, and THW decreased from VI to VIII.
Antennule: present in 20 of the 42 larvae confirmed as $P$. inflatus. The three segments of the peduncle, almost as long as the first segment of the antennule during stages $\mathrm{V}$ and VI. From VI onwards, the endopod increased in size. Setae of peduncle: first (basal) segment with $0-2$, usually 2 ; in the central part and outer margin with 0 or 1 on the distal end, and second segment with $0-2$ distal setae; aesthetascs of the exopods occur from stage VII: 1 or 2 at VII and 6 at VIII and IX (Fig. $4 \mathrm{~A}-\mathrm{E})$. 


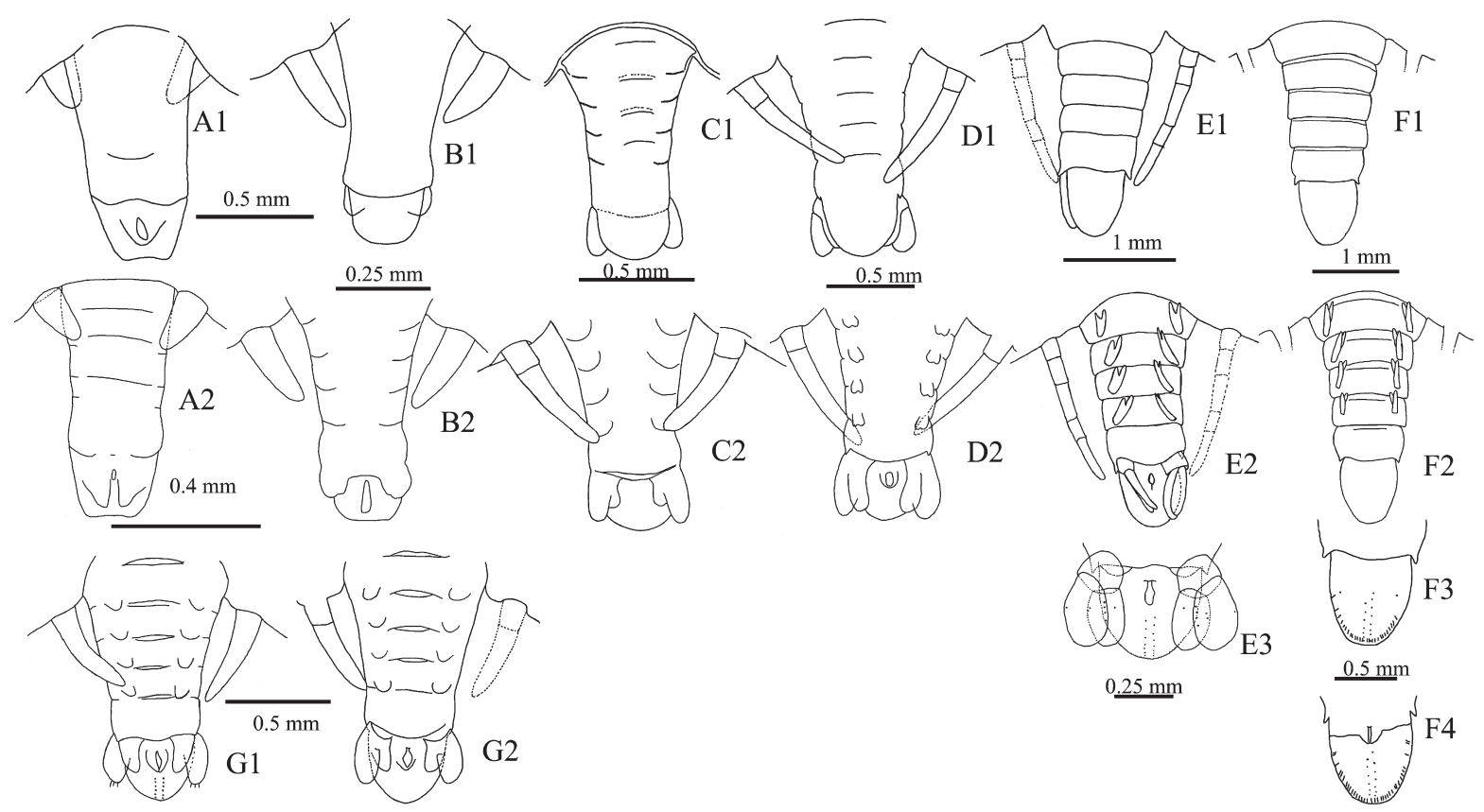

Figure 3. Abdomen and telson of Panulirus inflatus (A-F) and P. gracilis (G) (1 ventral view; 2 dorsal view; A = V; B = VI; C = VII; $\mathrm{D}$ and $\mathrm{G}=\mathrm{VIII}, \mathrm{E}=\mathrm{IX} ; \mathrm{F}=\mathrm{X})$.

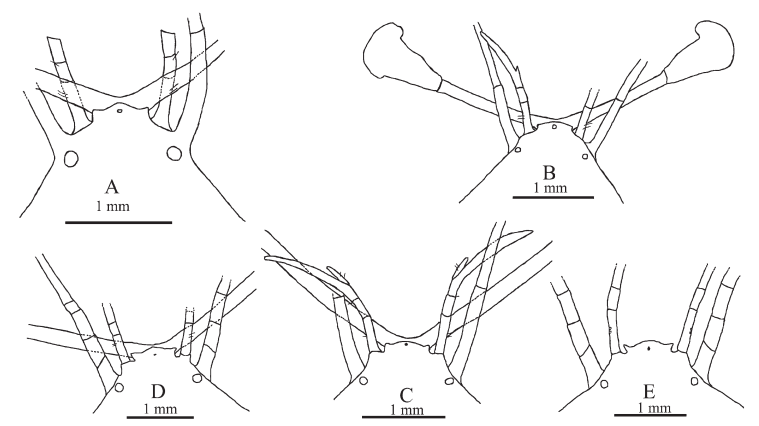

Figure 4. Upper margin of Panulirus inflatus cephalic region in different stages of development $(\mathrm{A}=\mathrm{V} ; \mathrm{B}=\mathrm{VI} ; \mathrm{C}=\mathrm{VII} ; \mathrm{D}$ = VIII; E = IX).

Panulirus gracilis: the three larvae available for morphological analysis had no fourth pereopod, and their initial classification was based on the presence or absence of the two setae in the middle of the outer margin of the first antennular segment (Báez, 1983). Stages VI and VII did not show these setae and were initially classified as $P$. inflatus, although later genetic analysis confirmed them as $P$. gracilis. Stage VIII had two setae.

Second maxillipeds of $P$. inflatus: present only in 5 larvae at VI, VII, and VIII, consisting of five segments with 2, 1, 1, 7, 4 setae during the three stages; exopod absent in VI and present in VII-VIII (Fig. 5A-D). P. gracilis larvae without second pair of maxillae.

First maxilla: present in $31 \mathrm{P}$. inflatus larvae. Basal endite with 2 or 3 long distal

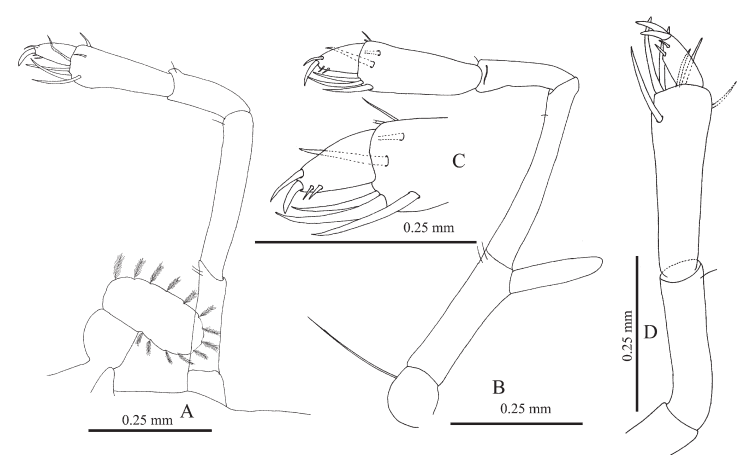

Figure 5. Second maxilliped of Panulirus inflatus in different stages of development (A = VI; B = VII; C = VIII).

serrulate spines ( 2 at V, 2 or 3 at VI, and 3 at VIII-X). Two short setae on the anterior margin $(\mathrm{V}-\mathrm{X})$; 1 or 2, rarely 3, subdistal spines ( 1 at $\mathrm{V}$ and VI, 2 at VII, and 1 to 3 at VIII to $\mathrm{X})$. Coxal endite with 2 rarely 3, long plumose distal spines $(\mathrm{V}-\mathrm{X}), 2$ or 3 subdistal spines or occasionally 1 or 4 , and 0 or 1 short posterior setae (Fig. 6A-F).

Second maxilla: P. inflatus scaphognathite with marginal plumose setae, 9 at V, 13-16 at VI, 20-24 at VII, 30-37 at VIII, 40-44 at IX, and 50 at $\mathrm{X}$; protopod with $0-3$ short setae in the outer margin of the maxilla (Fig. 7A-F).

Second maxilla: found only at VII of P. gracilis. Scaphognathite with 42 marginal plumose setae evenly distributed. Protopod with no setae in the external margin (Fig. 7G). 


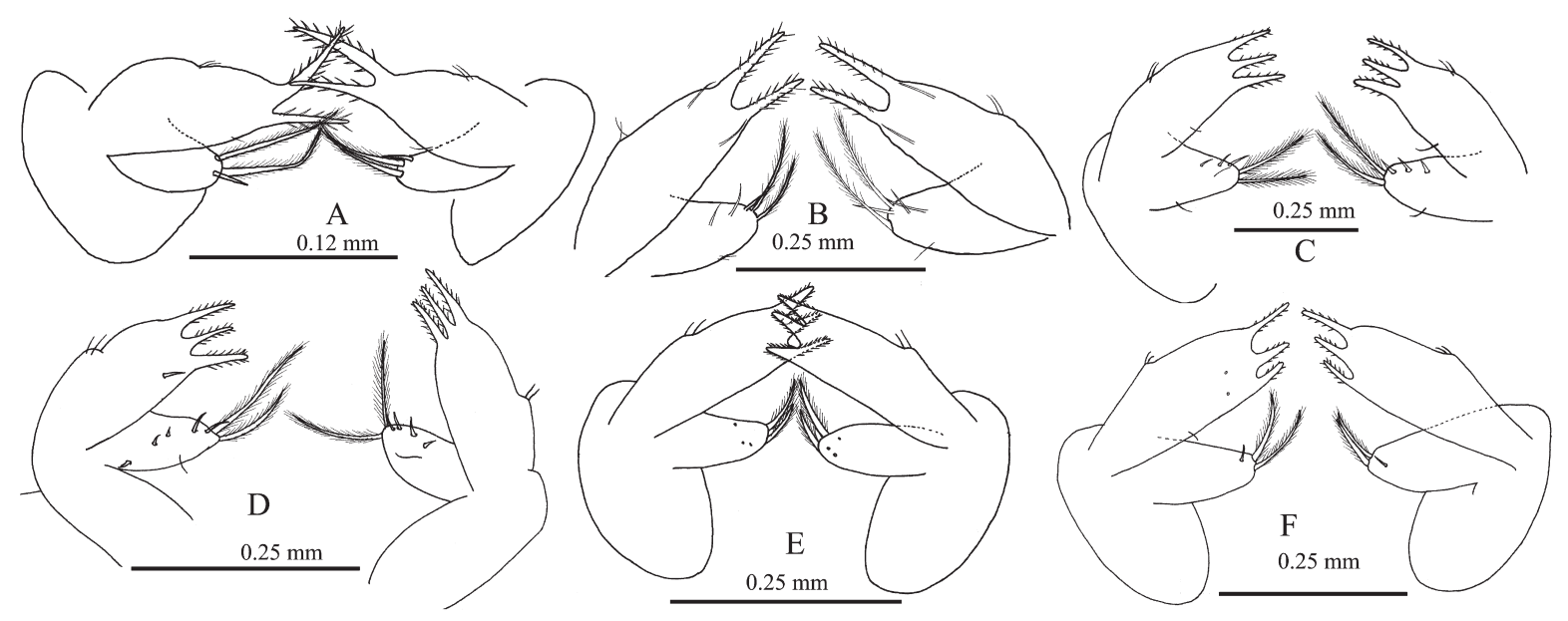

Figure 6. First maxilla of Panulirus inflatus in different stages of development $(\mathrm{A}=\mathrm{V} ; \mathrm{B}=\mathrm{VI} ; \mathrm{C}=\mathrm{VII} ; \mathrm{D}=\mathrm{VIII} ; \mathrm{E}=\mathrm{IX} ; \mathrm{F}=\mathrm{X})$.

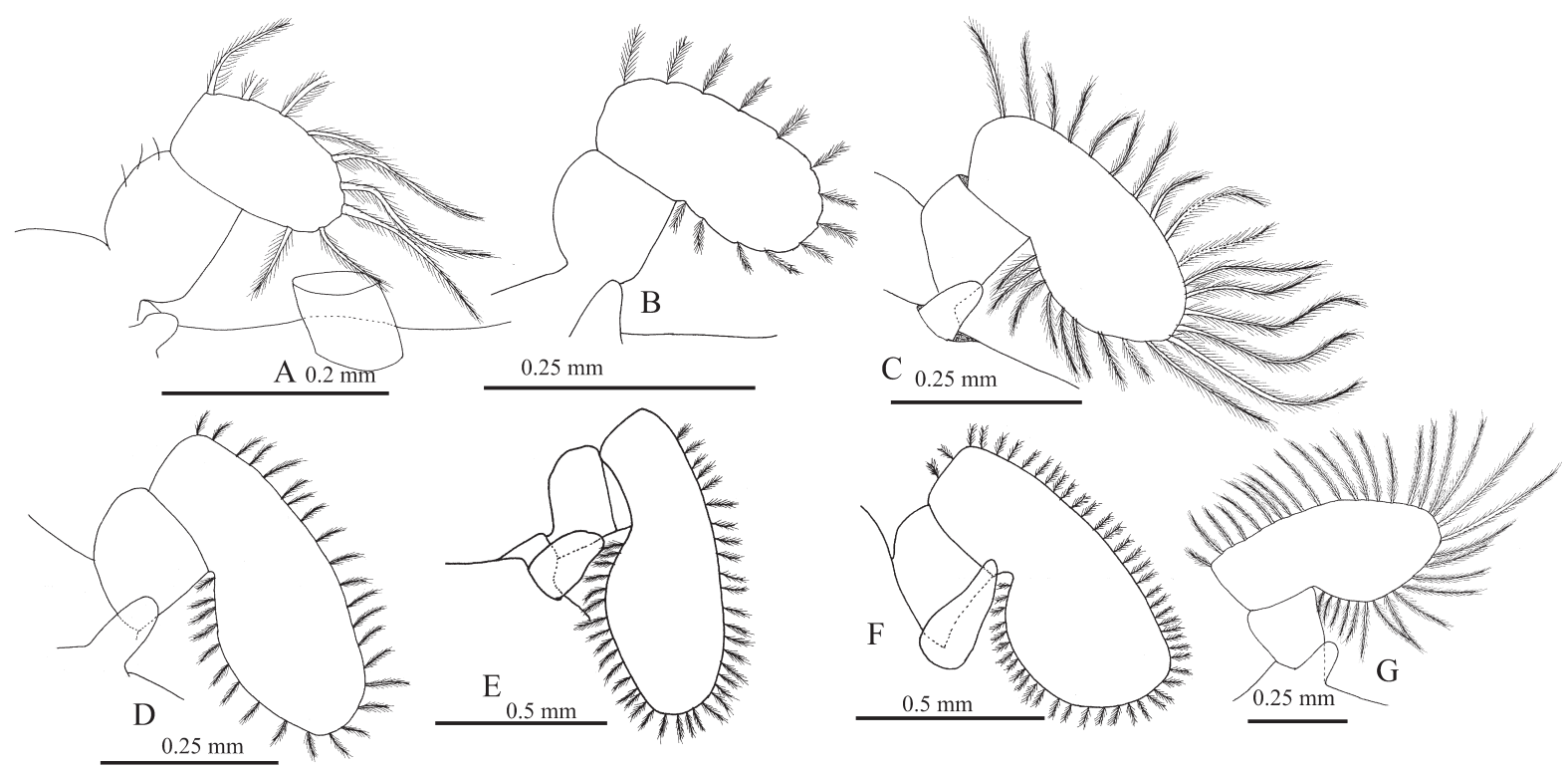

Figure 7. Second maxilla of Panulirus inflatus $(\mathrm{A}-\mathrm{F})$ and P. gracilis $(\mathrm{G})$, in different stages of development $(\mathrm{A}=\mathrm{V} ; \mathrm{B}=\mathrm{VI} ; \mathrm{C}=\mathrm{VII}$; $\mathrm{D}$ and $\mathrm{G}=\mathrm{VIII} ; \mathrm{E}=\mathrm{IX} ; \mathrm{F}=\mathrm{X} ; \mathrm{A}, \mathrm{E}$, and G left side; $\mathrm{B}, \mathrm{C}, \mathrm{D}$, and F right side).

Mandibles: $P$ inflatus. Asymmetric teeth at all stages. Right: incisor process with three strong terminal teeth at all stages, molar process and medial gnathal edge with a series of marginal denticles ranging from 2 at $\mathrm{V}$ to 11 at X. Left: incisor process with four strong terminal teeth at all stages, medial gnathal edge and molar process crowned with many papillae (Fig. 8A-F).

Mandibles: P. gracilis. With asymmetric dentition at stages VI- VII. Right: incisor process with three strong terminal teeth in the three stages, molar process and the medial gnathal edge without marginal denticles and crowned with many papillae. Left: incisor process with four strong terminal teeth and middle gnathal edge and molar process, crowned by many papillae at VII (Fig. 8G-I).

Panulirus inflatus. A lip with a filter press at distal end present at the rear of the mandible at the beginning of the digestive tract (Fig. 9E). Mikami and Takashima (2000) and Chakraborty et al. (2011) indicate that filter press has filtering functions for particles that have been previously chewed in the buccal apparatus.

Pereopods: Most of the larvae had missing pereopods. Counting the setae at the base of the pereopods showed no definite pattern, since they varied from 0 to 7 and had no spines (Fig. 10A-B). Of 35 P. inflatus larvae studied, 25 had the 4 th pereopod, but 


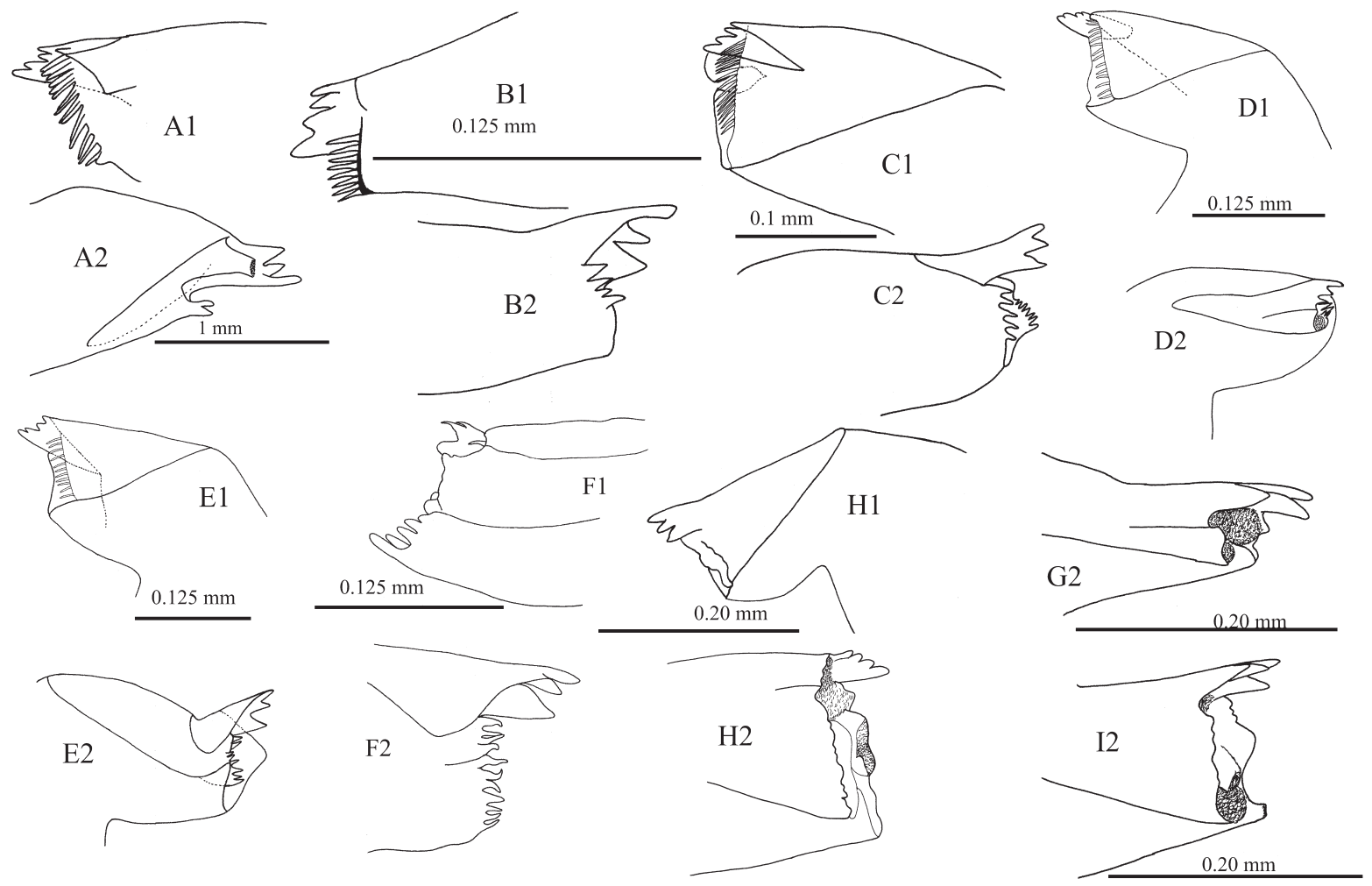

Figure 8. Mandibles of Panulirus inflatus $(\mathrm{A}-\mathrm{F})$ and P. gracilis $(\mathrm{G}-\mathrm{I})$ in different stages of development $(1 ; \mathrm{A}=\mathrm{V} ; \mathrm{B}$ and $\mathrm{G}=\mathrm{VI}$; C and $\mathrm{H}=\mathrm{VII} ; \mathrm{D}$ and $\mathrm{I}=\mathrm{VIII}, \mathrm{E}=\mathrm{IX} ; \mathrm{F}=\mathrm{X})$.

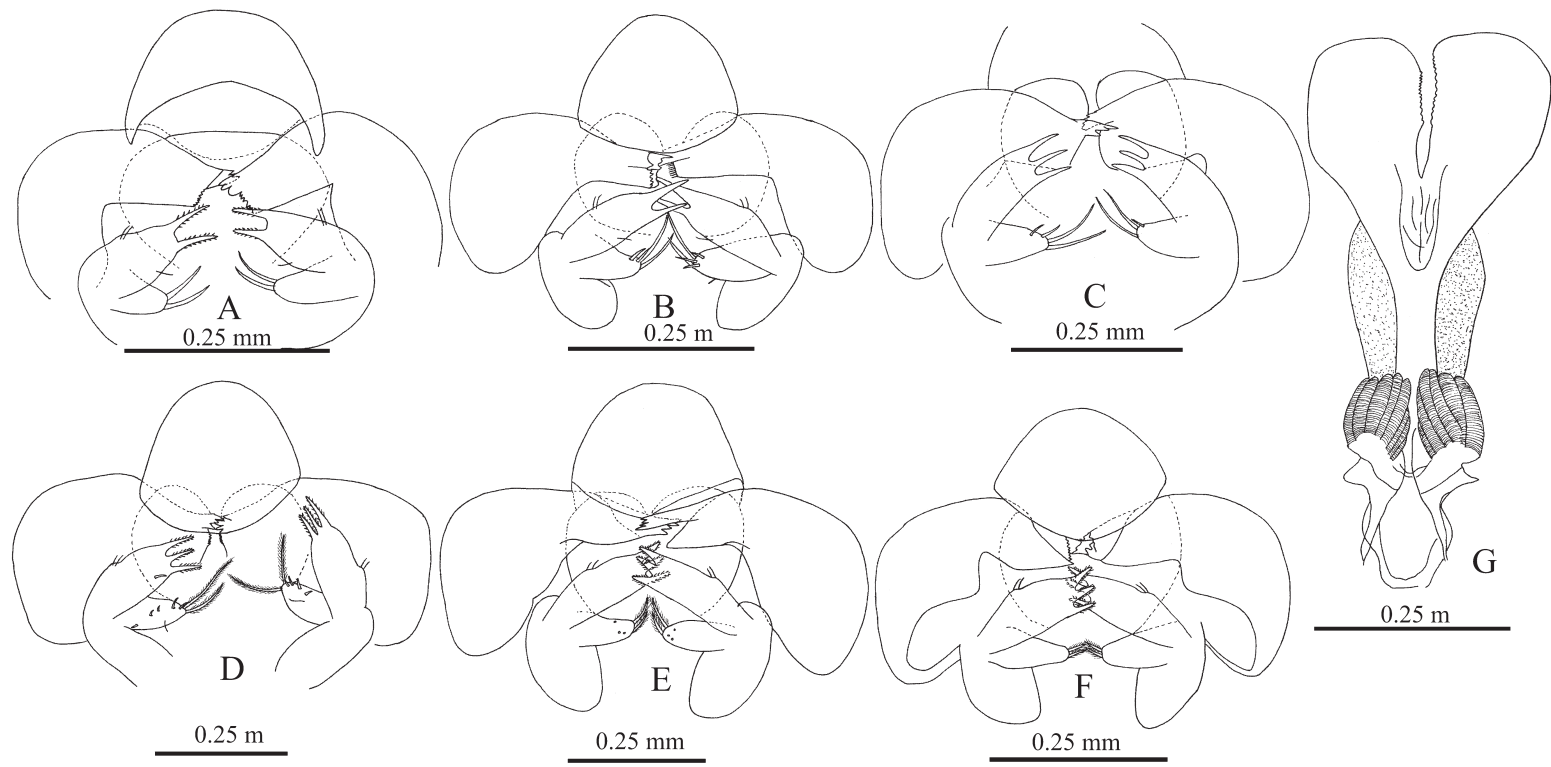

Figure 9. Buccal appendage and digestive tract components of Panulirus inflatus in different stages of development $(A=V ; B=V I$; $\mathrm{C}=\mathrm{VII} ; \mathrm{D}$ and $\mathrm{G}=\mathrm{VIII} ; \mathrm{E}=\mathrm{IX} ; \mathrm{F}=\mathrm{X} ; \mathrm{L}=$ lip; $\mathrm{ES}=$ esophagus; $\mathrm{PV}=$ proventriculus; $\mathrm{PF}=$ filter press).

none had subexopodal spines. At stage V, the endopod and exopod of the 4th pereopod were the same size, a feature indicated by Johnson and Knight (1966) as peculiar to P. inflatus. The fourth pereopod was missing in $P$. gracilis larvae, but the first and second had three spines at the base, which were not observed in any of the P. inflatus larvae (Fig. 10A).

Six larvae that were not subjected to genetic analysis ( 1 at V, 2 at IX, and 3 at X) and one confirmed as $P$. gracilis (at XI) by the RFLP analysis had subexopodal spines in the 


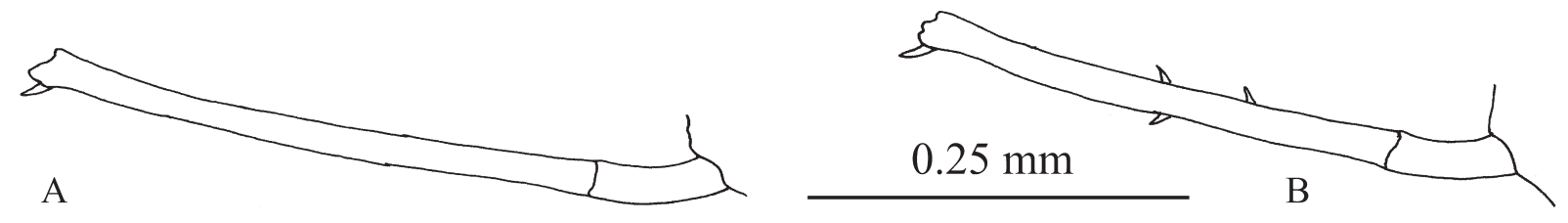

Figure 10. Second pereopod of Panulirus inflatus VIII (A) and P. gracilis VIII (B).

Table 3. Subexopodal spines on the pereopods by species and larval stage.

\begin{tabular}{|c|c|c|c|c|c|c|c|c|c|c|}
\hline \multirow[b]{2}{*}{ Pereopods } & \multicolumn{6}{|c|}{ Panulirus inflatus } & \multicolumn{4}{|c|}{ Panulirus gracilis } \\
\hline & $\begin{array}{c}\mathrm{V} \\
(\mathrm{n}=1)\end{array}$ & $\begin{array}{c}\mathrm{VI} \\
(\mathrm{n}=7)\end{array}$ & $\begin{array}{c}\mathrm{VII} \\
(\mathrm{n}=10)\end{array}$ & $\begin{array}{c}\text { VIII } \\
(\mathrm{n}=10)\end{array}$ & $\begin{array}{c}\mathrm{IX} \\
(\mathrm{n}=6)\end{array}$ & $\begin{array}{c}\mathrm{X} \\
(\mathrm{n}=1) \\
\end{array}$ & $\begin{array}{c}\mathrm{V}^{*} \\
(\mathrm{n}=1)\end{array}$ & $\begin{array}{c}\mathrm{IX}^{*} \\
(\mathrm{n}=2)\end{array}$ & $\begin{array}{c}\mathrm{X}^{*} \\
(\mathrm{n}=3)\end{array}$ & $\begin{array}{c}\mathrm{XI} \\
(\mathrm{n}=1)\end{array}$ \\
\hline 1 & $\mathrm{P}$ & $\mathrm{P}$ & $\mathrm{P}$ & $\mathrm{P}$ & $\mathrm{P}$ & $\mathrm{P}$ & $\mathrm{P}$ & $\mathrm{P}$ & $\mathrm{P}$ & $\mathrm{P}$ \\
\hline 2 & $\mathrm{X}$ & $\mathrm{P}$ & $\mathrm{P}$ & $\mathrm{P}$ & $\mathrm{X}$ & $\mathrm{P}$ & $\mathrm{P}$ & $\mathrm{P}$ & $\mathrm{P}$ & $\mathrm{P}$ \\
\hline 3 & $\mathrm{X}$ & $\mathrm{P}$ & $\mathrm{P}$ & $\mathrm{X}$ & $\mathrm{X}$ & $\mathrm{X}$ & $\mathrm{P}$ & $\mathrm{P}$ & $\mathrm{P}$ & $\mathrm{P}$ \\
\hline 4 & A & A & A & $\mathrm{X}$ & $\mathrm{X}$ & $\mathrm{X}$ & $\mathrm{P}$ & $\mathrm{P}$ & $\mathrm{P}$ & $\mathrm{P}$ \\
\hline
\end{tabular}

Table 4. Number of spines in the bases of the pereopods by species and larval stage.

\begin{tabular}{|c|c|c|c|c|c|c|c|c|c|c|}
\hline \multirow{2}{*}{ Pereopods } & \multicolumn{6}{|c|}{ Panulirus inflatus } & \multicolumn{4}{|c|}{ Panulirus gracilis } \\
\hline & $\begin{array}{c}\mathrm{V} \\
(\mathrm{n}=1)\end{array}$ & $\begin{array}{c}\mathrm{VI} \\
(\mathrm{n}=7)\end{array}$ & $\begin{array}{c}\text { VII } \\
(\mathrm{n}=10)\end{array}$ & $\begin{array}{c}\text { VIII } \\
(\mathrm{n}=10)\end{array}$ & $\begin{array}{c}\mathrm{IX} \\
(\mathrm{n}=6)\end{array}$ & $\begin{array}{c}\mathrm{X} \\
(\mathrm{n}=1)\end{array}$ & $\begin{array}{c}V^{*} \\
(n=1)\end{array}$ & $\begin{array}{c}\mathrm{IX}^{*} \\
(\mathrm{n}=2) \\
\end{array}$ & $\begin{array}{c}\mathrm{X}^{*} \\
(\mathrm{n}=3) \\
\end{array}$ & $\begin{array}{c}\mathrm{XI} \\
(\mathrm{n}=1) \\
\end{array}$ \\
\hline 1 & 0 & 0 & 0 & 0 & 0 & 0 & 0 & $0-1$ & 1 & 1 \\
\hline 2 & $\mathrm{X}$ & 0 & 0 & 0 & $\mathrm{X}$ & 0 & $0-1$ & $1-3$ & $1-3$ & 3 \\
\hline 3 & $\mathrm{X}$ & 0 & 0 & $\mathrm{X}$ & $\mathrm{X}$ & $\mathrm{X}$ & $0-1$ & 3 & 3 & $2-3$ \\
\hline 4 & 0 & 0 & 0 & $\mathrm{X}$ & $\mathrm{X}$ & $\mathrm{X}$ & 0 & 3 & 3 & 3 \\
\hline
\end{tabular}

four pereopods (P1, P2, P3, P4), with spines at their base $(0$ or 1 in $\mathrm{P} 2$ and $\mathrm{P} 3$ at $\mathrm{V} ; 0$ or 1 in $\mathrm{P} 1$ at IX, X, and XI; $1-3$ in P2, P3, and $\mathrm{P} 4$, most commonly 3 at IX and $\mathrm{X}$; 1 in P1, 3 in $\mathrm{P} 2$ and $\mathrm{P} 4$; and $2-3$, in $\mathrm{P} 3$ at XI) (Tabs. 3 and 4$)$.

\section{Discussion}

All body measurements of phyllosoma stages VI-VIII) overlapped in the two species; thus, discrimination was not possible across the morphometric data. For example, increases in size from VI and VIII of both species were similar with the exception of BAM and BAL, which were greater in $P$. inflatus $(100 \%$ and $70 \%$, respectively) than in $P$ gracilis $(70.7 \%$ and $16.7 \%$ ). However, the ranges of these measurements overlapped. The ratio between LEC and AEC decreased (1.6 to 1.3) because width increased more than length. Johnson and
Knight (1966) indicate that P. inflatus at stage XI has a ratio of 1.2, which would confirm the trend. Also, the abdomen, pleopods, and uropods showed similar characteristics in both species during stages VI-VIII.

Our results agree with Johnson and Knight (1966) for P. inflatus and Báez (1983) and Jaimes-Martínez and López-Peralta (2008) for P. gracilis. Johnson and Knight (1966) consider all their specimen larvae as $P$. inflatus by the fact that these were collected in the area of distribution of adults of this species. However, some figures (Figs. 23 and 26, Page 39) in their work show the presence of subexopodal spines on the $\mathrm{P} 4$ and spines on the base of the pereopods (P1, P2, P3, and P4, Fig. 32, Page 43), a feature that occurred only in the larvae of $P$ gracilis in our study.

The spines are shown in Fig. 32 of Johnson and Knight (1966) (stage XI; P1 with 1 spine and P2, P3, and P4 with 3 spines), 
although the authors did not comment on their presence. Moreover, the same figure shows this larva with subexopodal spines in the four pereopods, which according to Johnson (1971) is a specific feature of $P$. gracilis. The absence of these spines at the base of the pereopods in $P$. inflatus and their presence in $P$. gracilis are of taxonomic value to distinguish the two species, as suggested by Báez (1983).

In view of the difference between the number of setae of second maxilla at stages VII of the two species (30-37 in P. inflatus and 42 in $P$. gracilis), it seems advisable to analyze this structure in other stages to corroborate their taxonomic value. Johnson and Knight (1966) did not indicate the number of setae in the second maxillae of $P$. inflatus, but their illustrations (Figs. 23 and 26, Page 39) show 23 setae for stage VII and 37 setae for stages VIII, corroborating our results.

Báez (1983) suggested the presence of setae in the central part of the outer margin of the first antennular segment and on the outer margin of the third segment of the second maxilliped as unique to $P$ gracilis, but our study showed that setae are also present in $P$. inflatus. For this reason, neither feature can be used to differentiate these two species.

The mandibles showed clear differences between the two species and could be of taxonomic value for differentiation.

Our study agrees with information reported by other authors; however, we provide a review of the larval taxonomy of these species that is supported by genetic identification, confirming the taxonomic value of the structures that were used for differentiating between the two species, and to find other structures that were less fragile than pereopods. This provided an accurate way to differentiate.

In summary, since the ranges of variation of morphometric measurements are similar in both species, these cannot be used for taxonomic differentiation. However, the following morphological features can be used for differentiating $P$. inflatus larvae from $P$. gracilis larvae.

Stages V-X of Panulirus inflatus has no subexopodal spines on the fourth pereopods, nor spines at the base of any of its pereopods.
Marginal denticles are present in the molar processes and on the margin of the gnathal edges of the right mandible. Between 30 and 37 plumose setae are regularly distributed around the scaphognathite at stage VII.

Panulirus gracilis has 0 or 1 spine at the base of the first pereopods and 1-3, usually 3 , at the base of the second, third, and fourth pereopods in stages VII, IX, X, and XI. No marginal denticles are present in the molar processes, and the median gnathal edges of the right mandible during stages VI-VIII. At stage VII, there are 42 plumose setae regularly distributed around the scaphognathite.

ACKNOWLEDGEMENTS - We thank the crew of the SSV Robert. C. Seamans of the SEA Education Association at Woods Hole, Massachusetts and the Marine Biology Laboratory for donating phyllosoma specimens. We thank Michel Hendrickx for the use of facilities and equipment for preparing figures and Domenico Voltolina of CIBNOR at Mazatlan for review and suggestions. Editorial services were provided by Ira Fogel of CIBNOR. TThe project was partly funded by the UAS-FACIMAR by a grant to IMG, and by CIBNOR by a grant to RPE and by IPN-CICIMAR by a grant to RGA.

\section{REFERENCES}

Báez, R.P. 1983. Larvas phyllosoma y puerulus de la langosta verde Panulirus gracilis Streets 1871 procedentes de la expedición Costa Rica, 1973 (Crustacea: Decapoda: Palinuridae). Revista de Biología Marina, 19(1): 79-111.

Campos, E. 2007. Comentarios sobre la distribución de la langosta pinta Panulirus inflatus y la langosta roja P. interruptus (Crustacea: Palinuridae) en el Pacífico mexicano. Revista Mexicana de Biodiversidad, 78: 201-204.

Chakraborty, R.D.; Radhakrisnanm, E.V.; Sanil, N.K.; Thangaraja, R. and Unnikrishanan, C. 2011. Mouthpart morphology of phyllosoma of the tropical spiny lobster Panulirus homarus (Linnaeus, 1758). Indian Journal of Fisheries, 58: 1-7.

Chapa-Saldaña, H. 1964. Contribución al conocimiento de las langostas del Pacífico mexicano y su pesquería. Instituto Nacional de Investigaciones Biológicas y Pesqueras. Secretaría de Industria y Comercio, México. Publ. No. 6. 68 p.

García-Rodríguez F.J.; Ponce-Díaz, G.; Muñoz-García, I.; González-Armas, R. and Pérez-Enriquez, R. 2008. Mitochondrial DNA markers to identify commercial spiny lobster species (Panulirus spp.) from the Pacific coast of Mexico: an application on phyllosoma larvae. Fishery Bulletin, 106: 204-212.

Hendrickx, M.E. 1995. LANGOSTAS (Langostas espinosas, bogavantes, cigarras y zapateras, langostas de lodo, etc.). p 383-415. In: W. Fischer, F. Krupp, W. Schneider, C. Sommer, K.E. Carpenter and V.H. Niem (eds), Guía FAO para la identificación de especies para los fines de la pesca. Pacífico centroOriental, Vol. I. Plantas e Invertebrados, FAO, Rome. 
Holthuis, L.B. and Villalobos, A. 1962. Panulirus gracilis Streets y Panulirus inflatus (Bouvier) dos especies de langostas (Crustacea: Decapoda) de la costa del Pacífico de América. Anales del Instituto de Biología. Universidad Nacional Autónoma de México, 32(1-2): 251-276.

Jaimes-Martínez, J.C. and López-Peralta, R.H. 2008. Larvas filosomas de langosta espinosa Panulirus gracilis en el océano Pacífico colombiano, septiembre de 2007. Boletín Cientifico CCCP, (15): 33-45.

Johnson, M.W. 1956. The larval development of the California spiny lobster Panulirus interruptus (Randall), with notes on P. gracilis Streets. Proceedings of the California Academy of Sciences, Fourth Series, 29(1): 1-19.

Johnson, M.W. and Knight, M. 1966. The phyllosoma larvae of the spiny lobster Panulirus inflatus (Bouvier). Crustaceana, 10(1): 31-47.

Johnson, M.W. 1971. The palinurid and scyllarid lobster larvae of the Tropical Eastern Pacific, and their distribution as related to the prevailing hydrography. Bulletin of the Scripps Institution of Oceanography, 19: 639-647.

Mikami, S. and Takashima, F. 2000. Functional morphology of the digestive system. p. 601-6010. In: B.F Phillips and J. Kittaka (eds), Spiny Lobsters: Fisheries and Culture. Fishing News Books. Oxford, UK.

Palumbi, S.R.; Martin, A.; Romano, S.; McMillan, W.O.; Stice, L. and Grabowski, G. 1991. A Simple Fool's Guide to PCR, ver. 2.0. Special publication of the Department of Zoology and Kewalo Marine Laboratory, University of Hawaii, University, Hawaii, Honolulu, 46 p.

Richardson D.E.; Vanwye, J.D.; Exum, A.M.; Cowen, R.K. and Crawford, D.L. 2007. High-throughput species identification: from DNA isolation to bioinformatics. Molecular Ecology Notes, 7: 199-207.

Watling, L. 1989. A classification system for crustacean setae based on the homology concept. p. 15-26. In: B.E. Felgenhauer, L. Watling and A.B. Thistle (eds), Functional morphology of feeding and grooming in Crustacea. Crustacean Issues 6. Rotterdam, The Netherlands. 